\title{
Regio- and Enantioselective Hydrogenation Using a Peptide Catalyst
}

Polymer-Supported

Synthesis

Key words

$\alpha, \beta, \gamma, \delta$-unsaturated aldehydes

Hantzsch esters

asymmetric transfer hydrogenation

peptide catalysis
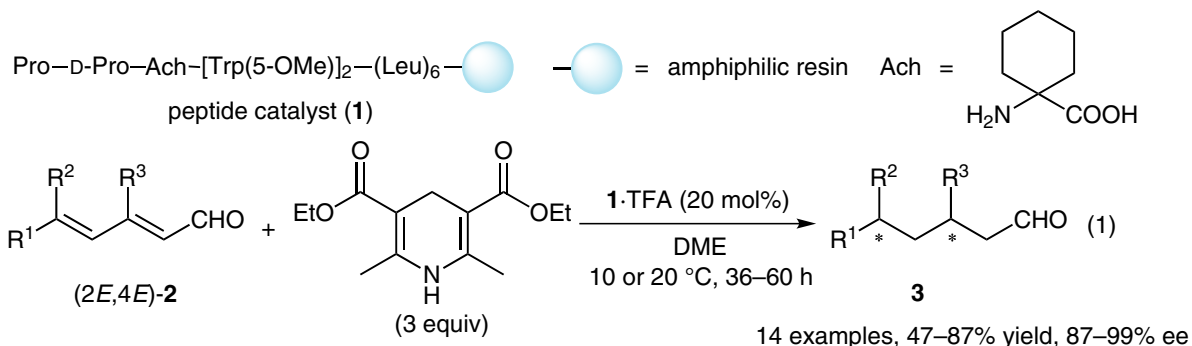

Selected examples:<smiles>[R]c1ccc(CC[C@@H](C)CC=O)cc1</smiles>

3a $\mathrm{R}=\mathrm{H}, 79 \%$ yield, $99 \%$ ee 3b R $=\mathrm{NO}_{2}, 75 \%$ yield, $97 \%$ ee 3c $\mathrm{R}=\mathrm{Cl}, 79 \%$ yield, $97 \%$ ee 3d $\mathrm{R}=\mathrm{Br}, 71 \%$ yield, $98 \%$ ee 3 e $\mathrm{R}=\mathrm{OMe}, 65 \%$ yield, $98 \%$ ee<smiles>C[C@H](CC=O)CCc1cccc(Cl)c1</smiles>

3f $74 \%$ yield, $98 \%$ ee<smiles>C[C@H](CC=O)CCc1ccsc1</smiles>

3h $64 \%$ yield, $98 \%$ ee<smiles>CCC(CC=O)CCc1ccccc1</smiles>

3j $47 \%$ yield, $97 \%$ ee<smiles>COc1ccc(C(C)CCCC=O)cc1</smiles>

3k $60 \%$ yield, $87 \%$ ee<smiles>C[C@H](CC=O)CCc1ccc2ccccc2c1</smiles>

3g $71 \%$ yield, $98 \%$ ee<smiles>C[C@@H](CC=O)CCC1CCCCC1</smiles>

$\mathrm{MeO}$

31 $87 \%$ yield, $d r=57: 43$,

$93 \%$ ee for major diastereomer $95 \%$ ee for minor diastereomer

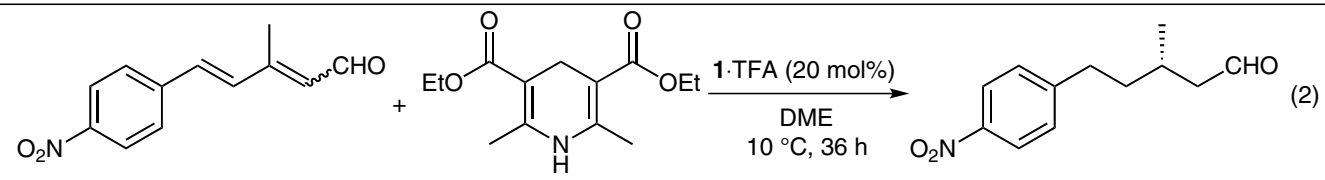

Significance: The amphiphilic resin-supported peptide 1 catalyzed the regio- and enantioselective transfer hydrogenation of $(2 E, 4 E)-\alpha, \beta, \gamma, \delta$ unsaturated aldehydes 2 with a Hantzsch ester to give the corresponding aldehydes 3 in $47-87 \%$ yield with $87-99 \%$ ee (14 examples, eq. 1).
Comment: In the hydrogenation of the mixture of $(2 E, 4 E)-\mathbf{2} \mathbf{b}$ and $(2 Z, 4 E)-\mathbf{2} \mathbf{b}$, aldehyde $\mathbf{3 b}$ was obtained in $71 \%$ yield with $97 \%$ ee (eq. 2). The authors have previously reported the asymmetric transfer hydrogenation of $\alpha, \beta$-unsaturated aldehydes with a Hantzsch ester in the presence of resin-supported peptides (Org. Lett. 2008, 10, 2035; Tetrahedron: Asymmetry 2009, 20, 461). 


\section{Category}

Polymer-Supported Synthesis

\section{Key words}

platinum nanoclusters

alkylation methylquinolines alcohols
C. CHAUDHARI, S. M. A. H. SIDDIKI, K.-I. SHIMIZU* (HOKKAIDO UNIVERSITY, SAPPORO AND KYOTO UNIVERSITY, JAPAN)

Alkylation of 2-Methylquinoline with Alcohols under Additive-Free Conditions by $\mathrm{Al}_{2} \mathrm{O}_{3}$-Supported Pt Catalyst Tetrahedron Lett. 2013, 54, 6490-6493.

\section{Dehydrative Alkylation of 2-Methylquinoline with Alcohols Using $\mathrm{Pt} / \mathrm{Al}_{2} \mathrm{O}_{3}$}<smiles>Cc1ccc2ccccc2n1</smiles>
$75 \%$ yield<smiles>C[PH2+]CO</smiles>

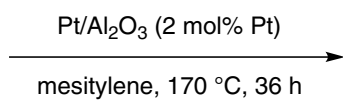

\section{Results:}<smiles>c1ccc(CCc2ccc3ccccc3n2)cc1</smiles>

$65 \%$ yield<smiles>CC(C)(C)c1ccc(CCc2ccc3ccccc3n2)cc1</smiles>

$60 \%$ yield<smiles>Clc1ccc(CCc2ccc3ccccc3n2)cc1</smiles>

$70 \%$ yield<smiles>Fc1ccc(CCc2ccc3ccccc3n2)cc1</smiles>

$42 \%$ yield<smiles>CCCCCCCOCCc1ccc2ccccc2n1</smiles>

$55 \%$ yield (in undecane at $200^{\circ} \mathrm{C}$ )<smiles>CCCCCCCCc1ccc2ccccc2n1</smiles>

$50 \%$ yield (in undecane at $200^{\circ} \mathrm{C}$ )
Significance: The $\mathrm{Al}_{2} \mathrm{O}_{3}$-supported platinum nanoclusters $\left(\mathrm{Pt} / \mathrm{Al}_{2} \mathrm{O}_{3}\right)$ were prepared by mixing $\mathrm{Al}_{2} \mathrm{O}_{3}$ and an aqueous $\mathrm{HNO}_{3}$ solution of $\mathrm{Pt}\left(\mathrm{NO}_{3}\right)_{2}\left(\mathrm{NH}_{3}\right)_{2}$ followed by reduction with hydrogen (eq. 1). $\mathrm{Pt} / \mathrm{Al}_{2} \mathrm{O}_{3}$ catalyzed the dehydrative alkylation of 2-methylquinoline with alcohols in mesitylene. The alkylation took place at the 2-methyl group to afford the corresponding alkylated products in up to $75 \%$ yield (7 examples). The catalyst was recovered by centrifugation, reactivated by reduction with hydrogen and reused four times with a slight decrease of its catalytic activity.
Comment: The $\mathrm{Pt} / \mathrm{Al}_{2} \mathrm{O}_{3}$ nanoclusters were characterized by XANES, EXAFS and $\mathrm{CO}$ adsorption analyses. In the reaction of 2-methylquinoline with benzyl alcohol, the catalytic activity of $\mathrm{Pt} / \mathrm{Al}_{2} \mathrm{O}_{3}$ was superior to that of the other $\mathrm{Al}_{2} \mathrm{O}_{3}$-supported metal catalysts $\left(\mathrm{Ir} / \mathrm{Al}_{2} \mathrm{O}_{3}: 53 \%\right.$ yield, $\mathrm{Rh} / \mathrm{Al}_{2} \mathrm{O}_{3}$ : $31 \%$ yield, $\mathrm{Pd} / \mathrm{Al}_{2} \mathrm{O}_{3}$ : $32 \%$ yield, $\mathrm{Ag} / \mathrm{Al}_{2} \mathrm{O}_{3}: 5 \%$ yield) and $\mathrm{Pt}$ nanoclusters supported on the other solid supports ( $\mathrm{Pt} / \mathrm{Nb}_{2} \mathrm{O}_{5}$ : 20\% yield, $\mathrm{Pt} / \mathrm{C}$ : $7 \%$ yield, $\mathrm{Pt} / \mathrm{ZrO}_{2}: 1 \%$ yield). ICP-AES analysis showed no leaching of $\mathrm{Pt}$ from the catalyst during the reaction. 


\section{Cyclopropanation of $\alpha, \beta$-Unsaturated Aldehydes with a Supported Peptide}

\section{Gategory}

Polymer-Supported

Synthesis

\section{Key words}

resin-supported peptides

asymmetric cyclopropanation

$\alpha, \beta$-unsaturated aldehydes
Significance: The amphiphilic resin-supported peptide 1 catalyzed the diastereo- and enantioselective cyclopropanation of aromatic $\alpha, \beta$-unsaturated aldehydes 2 with dimethylphenacylsulfonium bromide in the presence of $\mathrm{NaHCO}_{3}$ to give the corresponding cyclopropanes $\mathbf{3}$ in 83-88\% yield with 98-99\% ee and 92-97\% diastereoselectivity (9 examples, eq. 1). In the formation of $\mathbf{3 g}$, the catalyst was recovered by filtration and reused five times without significant loss of its catalytic performance $\left(1^{\text {st }}\right.$ reuse: $87 \%$ yield, 99\% ee, 94\% diastereoselectivity; $5^{\text {th }}$ reuse: $83 \%$ yield, 99\% ee, 95\% diastereoselectivity).
Comment: The authors have previously reported the preparation of a series of amphiphilic resinsupported peptides and their application to asymmetric hydrogenation (Org. Lett. 2008, 10, 2035), asymmetric Friedel-Crafts-type alkylation ( $A d v$. Synth. Catal. 2012, 354, 1280) and asymmetric Michael addition (Angew. Chem. Int. Ed. 2012, 51, 12786). 


\section{Category}

Polymer-Supported Synthesis

\section{Key words}

magnetic nanoparticles

cyclic 1,3-diones

activated acetonitriles

\section{isatins}

spirooxindoles
A. BAZGIR, G. HOSSEINI, R. GHAHREMANZADEH* (SHAHID BEHESHTI UNIVERSITY, TEHRAN AND AVICENNA RESEARCH INSTITUTE, TEHRAN, IRAN)

Copper Ferrite Nanoparticles: An Efficient and Reusable Nanocatalyst for a Green One-Pot, Three-Component Synthesis of Spirooxindoles in Water ACS Comb. Sci. 2013, 15, 530-534.

\section{Synthesis of Spirooxindoles Using $\mathrm{CuFe}_{2} \mathrm{O}_{4}$ Nanoparticles}

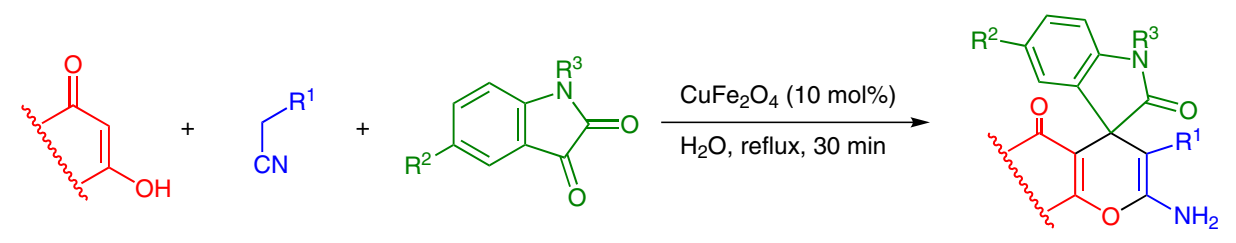

Selected examples:

38 examples, $81-97 \%$ yield<smiles>N#CC1=C(N)OC2=C(C3=CC=Cc4cccc(c42)C3=O)C12C(=O)Nc1ccccc12</smiles>

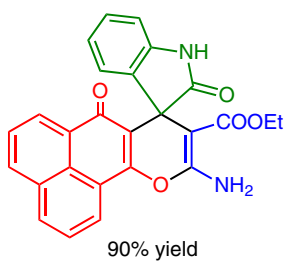<smiles></smiles>

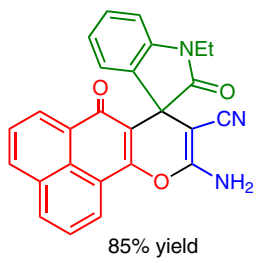

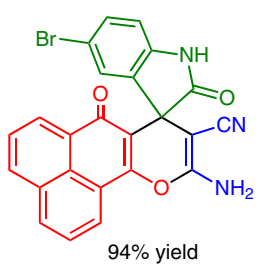

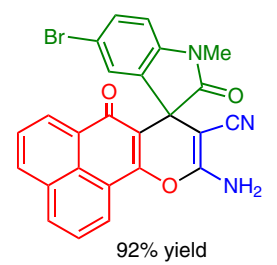

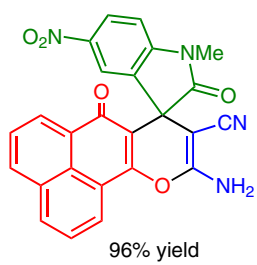<smiles>N#Cc1c(N)oc(=O)c2c1C(=O)C1c3ccccc3NC1O2</smiles>

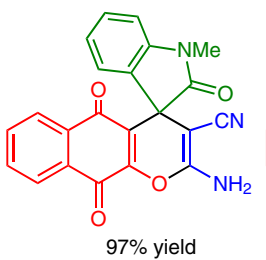

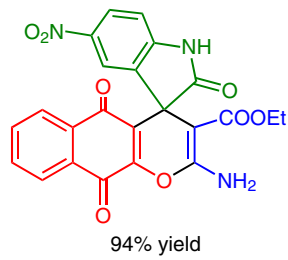

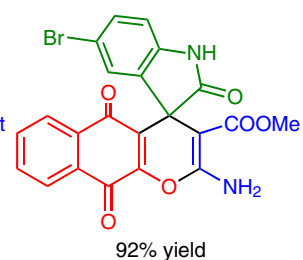<smiles></smiles><smiles>COC(=O)C1=C(N)Oc2nc(C)nc(O)c2C12C(=O)Nc1ccc([N+](=O)[O-])cc12</smiles>

$87 \%$ yield

$92 \%$ yield

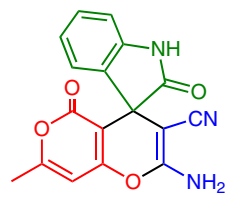

$84 \%$ yield

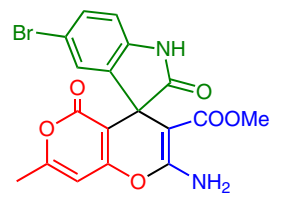

$96 \%$ yield
Significance: $\mathrm{CuFe}_{2} \mathrm{O}_{4}$ nanoparticles catalyzed the three-component coupling of cyclohexane1,3-diones, activated acetonitriles and isatins to give the corresponding spirooxindoles (38 examples, 81-97\% yield).
Comment: In the synthesis of product $\mathbf{A}$, the catalyst was recovered magnetically and reused four times ( $1^{\text {st }}$ reuse: $90 \%$ yield, $2^{\text {nd }}$ reuse: $89 \%$ yield, $3^{\text {rd }}$ reuse: $88 \%$ yield, $4^{\text {th }}$ reuse: $80 \%$ yield). 


\section{Suzuki-Miyaura Coupling Using Polymer- Stabilized Pd Nanoparticles}

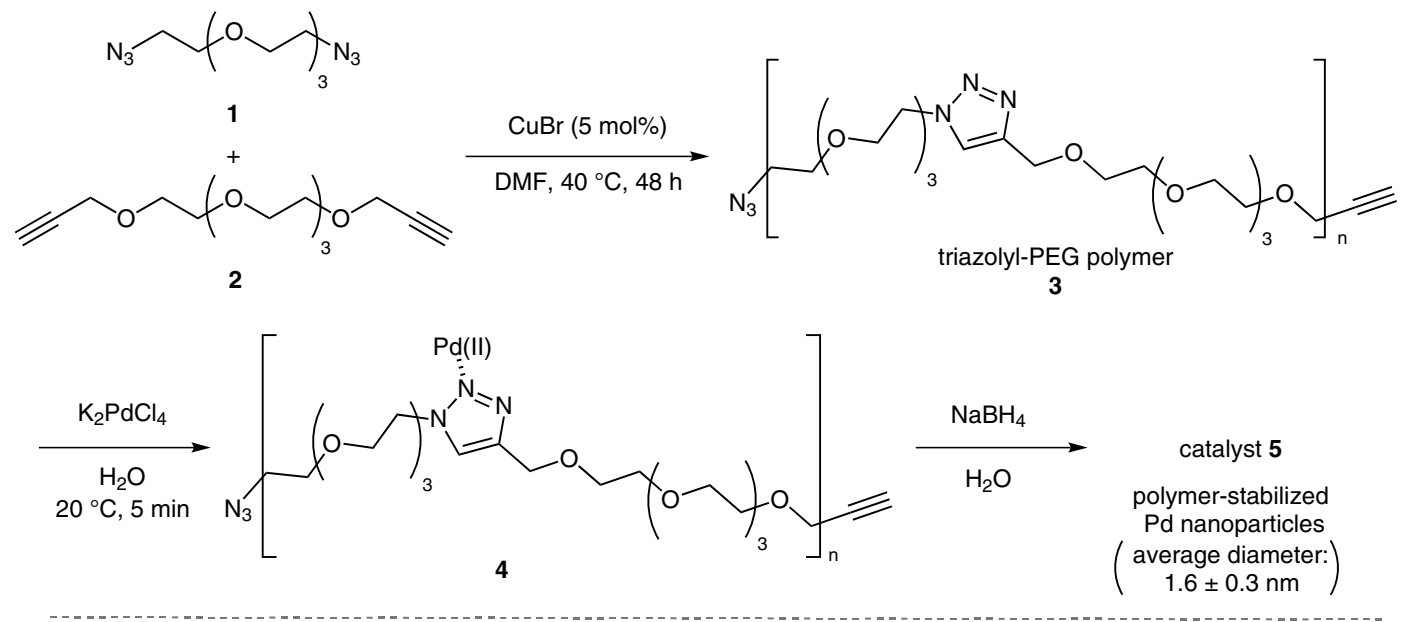

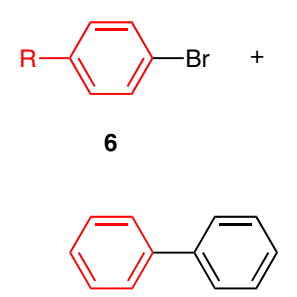

$8 \mathbf{a}$

$0.001 \mathrm{~mol} \% \mathrm{Pd}, 23 \mathrm{~h}: 99 \%$ yield

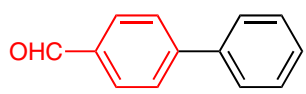

$8 d$

$0.01 \mathrm{~mol} \% \mathrm{Pd}, 24 \mathrm{~h}: 90 \%$ yield

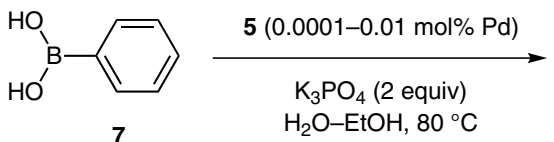

7

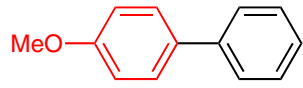

$8 b$

$0.001 \mathrm{~mol} \% \mathrm{Pd}, 20 \mathrm{~h}: 80 \%$ yield $0.002 \mathrm{~mol} \% \mathrm{Pd}, 20 \mathrm{~h}: 98 \%$ yield

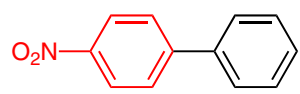

8 e

$0.001 \mathrm{~mol} \% \mathrm{Pd}, 2.5 \mathrm{~h}: 99 \%$ yield

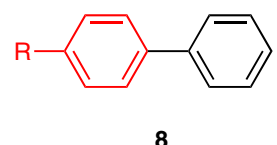

8

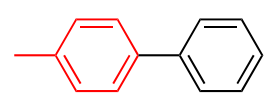

$8 c$

$0.001 \mathrm{~mol} \% \mathrm{Pd}, 24 \mathrm{h:}$ : $72 \%$ yield $0.002 \mathrm{~mol} \% \mathrm{Pd}, 20 \mathrm{~h}: 99 \%$ yield

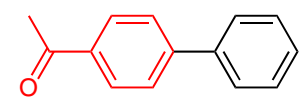

$8 f$

$0.0001 \mathrm{~mol} \% \mathrm{Pd}, 16 \mathrm{~h}: 99 \%$ yield $(\mathrm{TON}=990000)$

$0.001 \mathrm{~mol} \% \mathrm{Pd}, 0.5 \mathrm{~h}: 99 \%$ yield
Significance: Triazolyl-PEG polymer-stabilized palladium nanoparticles (PdNPs) 5 were prepared and applied to the Suzuki-Miyaura coupling. The reaction of aryl bromides 6 and phenylboronic acid (7) took place with $0.0001-0.01 \mathrm{~mol} \% \mathrm{Pd}$ of catalyst $\mathbf{5}$ to give the corresponding products $\mathbf{8}$ in 90-99\% yield. The turnover number (TON) reached up to 990000.
Comment: The Pd(II) catalyst $\mathbf{4}$ showed lower catalytic activity than the reduced catalyst $\mathbf{5}$ for the formation of $\mathbf{8}$ with $0.001 \mathrm{~mol} \% \mathrm{Pd}$. For a quantitative reaction of 4-bromoacetophenone and phenylboronic acid, 22 hours were needed with catalyst $\mathbf{4}$ instead of two hours with PdNP catalyst 5. The average diameter of the Pd nanoparticles of $\mathbf{5}$ is $1.6 \pm 0.3 \mathrm{~nm}$.

sYNFACTS Contributors: Yasuhiro Uozumi, Yoichi M. A. Yamada, Aya Ohno

Synfacts 2014, 10(1), $0101 \quad$ Published online: 13.12.2013

Dol: 10.1055/s-0033-1340379; Reg-No.: Y13213SF 


\section{Gategory}

Polymer-Supported Synthesis

\section{Key words}

bifunctional catalysis

gold nanoparticles

palladium nanoparticles organocatalysis aerobic oxidation asymmetric C-C bond formation
H. MIYAMURA, G. C. Y. CHOO, T. YASUKAWA, W.-J. YOO, S. KOBAYASHI* (THE UNIVERSITY OF TOKYO, JAPAN)

A Heterogeneous Layered Bifunctional Catalyst for the Integration of Aerobic Oxidation and Asymmetric $\mathrm{C}-\mathrm{C}$ Bond Formation

Chem. Commun. 2013, 49, 9917-9919.

\section{A Heterogeneous Bifunctional Au/Pd Nanoparticle Organocatalyst}
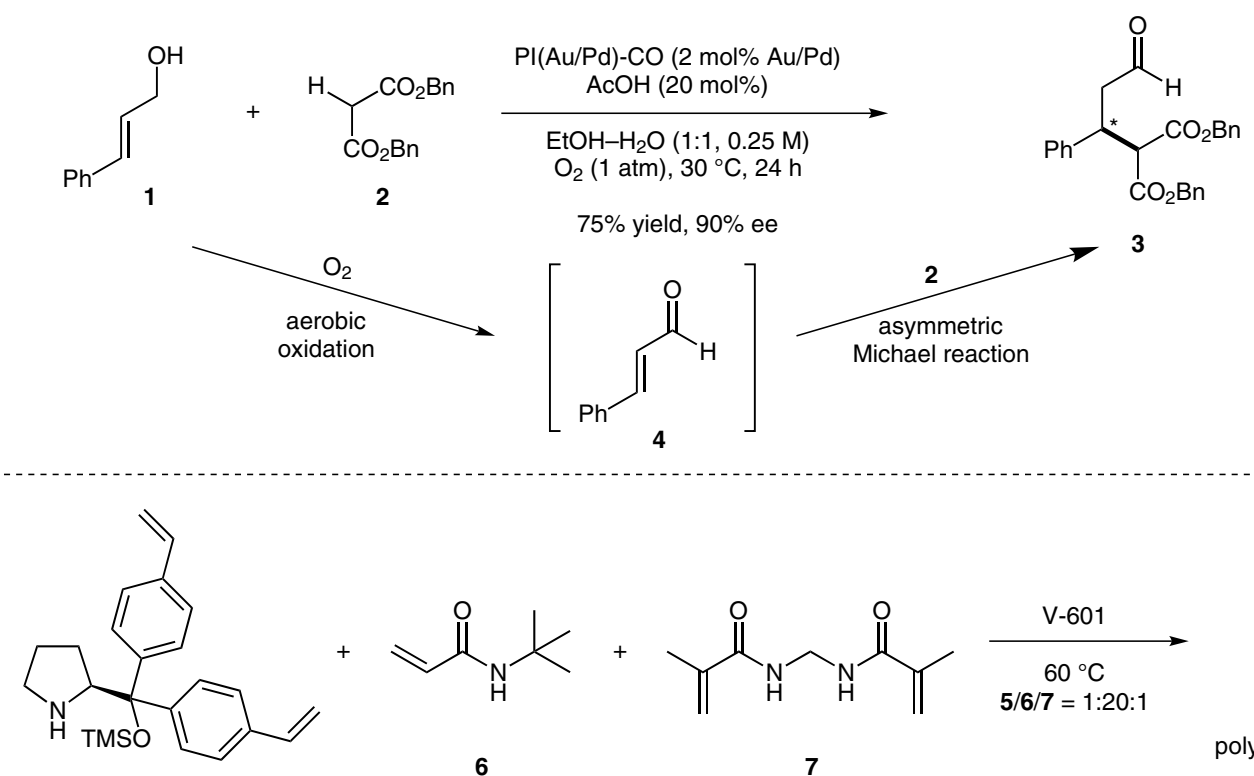

5<smiles>[CH+]C(C)(C)NC(=O)C=C</smiles>

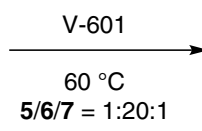

7

polymer beads 8<smiles>CC(C)(C)CC(c1ccc(C(C)(C)OCC(C)(C)O)cc1)C(C)(C)C(C)(C)CC(c1ccc(COCC2CO2)cc1)C(C)(C)C(C)(C)CC(c1ccccc1)C(C)(C)C</smiles>

1. polymer beads 8

2. $\mathrm{NaBH}_{4}$

3. $\mathrm{AuCl}\left(\mathrm{PPh}_{3}\right), \mathrm{Pd}(\mathrm{OAc})_{2}$

4. coacervate; then $150^{\circ} \mathrm{C}$

$\mathrm{PI}(\mathrm{Au} / \mathrm{Pd})-\mathrm{CO}$

Significance: The preparation of a polymer-incarcerated $\mathrm{Au} / \mathrm{Pd}$-coated organocatalyst [PI(Au/Pd)$\mathrm{CO}]$ for the sequential aerobic oxidation-Michael reaction between $\gamma$-substituted allylic alcohols and dibenzylmalonate was described. The reaction of 3-phenyl-2-propen-1-ol (1) and dibenzylmalonate (2) proceeded in the presence of $\mathrm{PI}(\mathrm{Au} / \mathrm{Pd})-\mathrm{CO}$ to give dibenzyl 2-(3-oxo-1-phenylpropyl)propanedioate (3) in 75\% yield with $90 \%$ ee (other 9 examples: $34-83 \%$ yield, $74-91 \%$ ee).
Comment: The Au/Pd organocatalyst was prepared by the copolymerization of monomers 5, 6 and $\mathbf{7}$ in the presence of $\mathrm{V}$-601 [dimethyl 2,2'-azobis(2-methylpropionate)] as a radical initiator followed by the formation of the cross-linked shell layer of a polymer $\mathbf{9}$ in which bimetallic Au/Pd nanoparticles were incorporated. Thus, $\mathrm{Pl}(\mathrm{Au} / \mathrm{Pd})$ $\mathrm{CO}$ was composed of an organocatalytic resin core and a polymeric Au/Pd nanoparticle shell. 
C. Rossy, J. MAJimel, E. Fouquet, C. Delacôte, M. Boujtita, C. LABrugère, M. TRÉGUER-DELAPIERRE,* F.-X. FELPIN* (UNIVERSITÉ DE NANTES, UNIVERSITÉ DE BORDEAUX, TALENCE AND UNIVERSITÉ DE BORDEAUX, PESSAC, FRANCE)

Stabilisation of Carbon-Supported Palladium Nanoparticles through the Formation of an Alloy with Gold: Application to the Sonogashira Reaction

Chem. Eur. J. 2013, 19, 14024-14029.

\section{Gategory}

Polymer-Supported Synthesis

\section{Key words}

bimetallic palladium gold nanoparticles

\section{Sonogashira Coupling with Bimetallic Pd-Au Nanoparticles on Carbon}

\section{carbon}

Sonogashira coupling

aryl iodides

alkynes

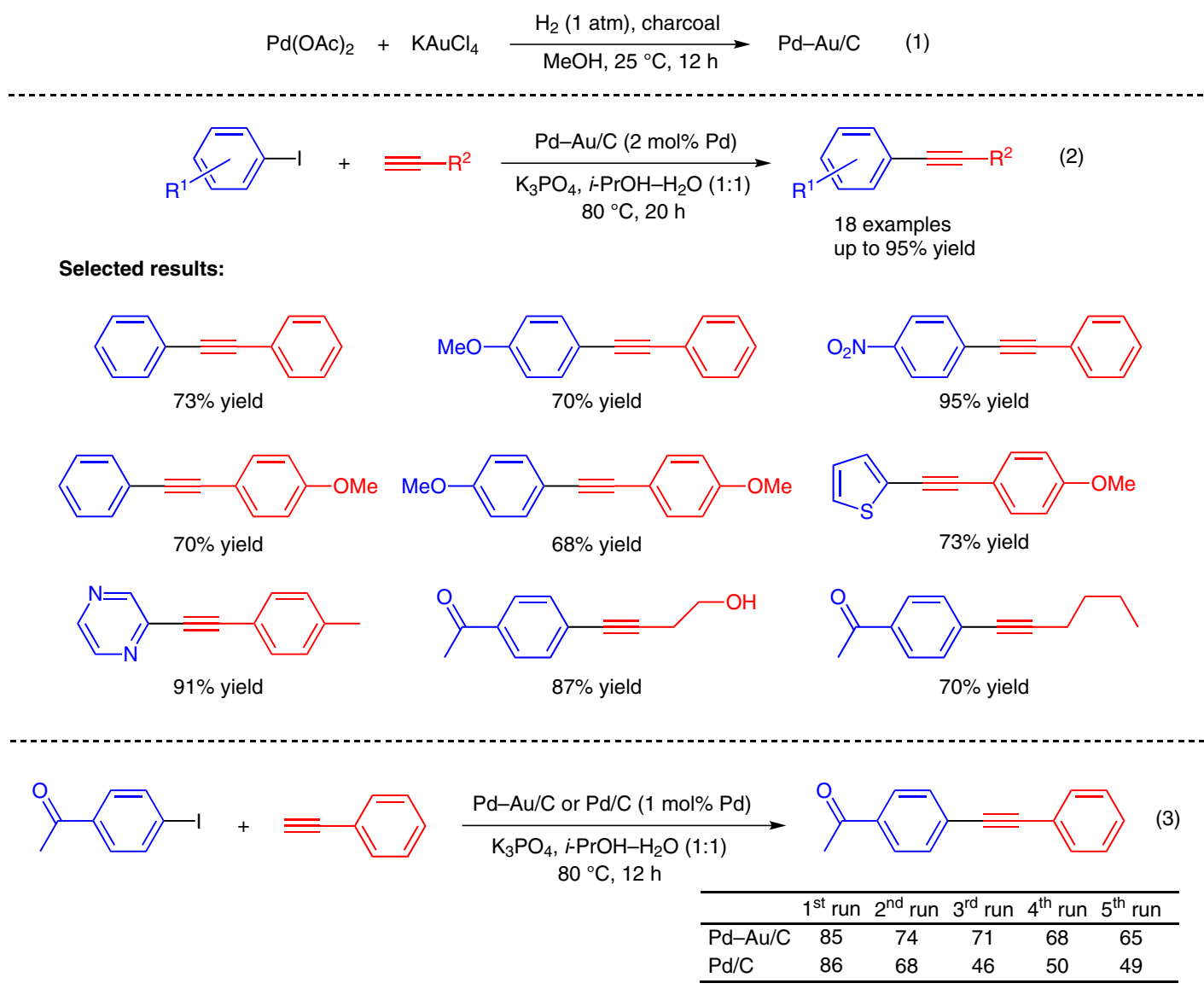

Significance: Bimetallic palladium-gold nanoparticles on carbon $(\mathrm{Pd}-\mathrm{Au} / \mathrm{C})$ were prepared by treatment of a mixture of $\mathrm{Pd}(\mathrm{OAc})_{2}, \mathrm{KAuCl}_{4}$ and charcoal in methanol with $\mathrm{H}_{2}$ (eq. 1). $\mathrm{Pd}-\mathrm{Au} / \mathrm{C}$ catalyzed the Sonogashira coupling of aryl iodides with terminal alkynes under copper-free conditions to give the corresponding diaryl alkynes in up to $95 \%$ yield (18 examples, eq. 2).
Comment: The Pd-Au/C nanoparticles were characterized by TEM, XRD, STEM-EDX, XPS and $\mathrm{CV}$ analyses. Though the catalytic activity of fresh $\mathrm{Pd}-\mathrm{Au} / \mathrm{C}$ was similar to that of fresh $\mathrm{Pd} / \mathrm{C}$, $\mathrm{Pd}-\mathrm{Au} / \mathrm{C}$ showed high stability during the recycling experiments (eq. 3). TEM analysis showed that the morphology of the recovered $\mathrm{Pd}-\mathrm{Au} / \mathrm{C}$ was unchanged after the third run. 


\section{Gategory}

Polymer-Supported Synthesis

\section{Key words}

palladium-zinc ferrite

cross-coupling

ligand-free

A. S. SINGH, S. S. SHENDAGE, J. M. NAGARKAR* (INSTITUTE OF CHEMICAL TECHNOLOGY, MUMBAI, INDIA)

Palladium Supported on Zinc Ferrite: An Efficient Catalyst for Ligand-Free C-C and C-O Cross-Coupling Reactions Tetrahedron Lett. 2013, 54, 6319-6323.

\section{Ligand-Free $\mathrm{C}-\mathrm{C}$ and $\mathrm{C}-\mathrm{O}$ Cross-Couplings with $\mathrm{Pd}-\mathrm{ZnFe}_{2} \mathrm{O}_{4}$}

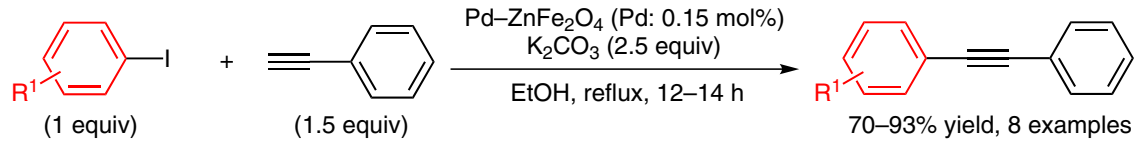

Selected results:

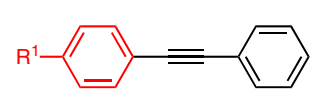

$\mathrm{R}^{1}=\mathrm{H} ; 90 \%$ yield $(12 \mathrm{~h})$ $R^{1}=$ Me; $82 \%$ yield $(13 \mathrm{~h})$ $\mathrm{R}^{1}=\mathrm{NO}_{2} ; 93 \%$ yield $(12 \mathrm{~h})$ $\mathrm{R}^{1}=\mathrm{Br} ; 70 \%$ yield $(12 \mathrm{~h})$

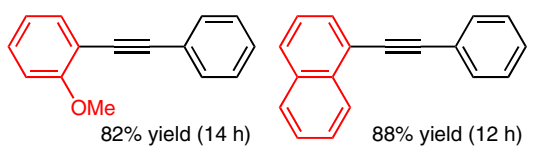

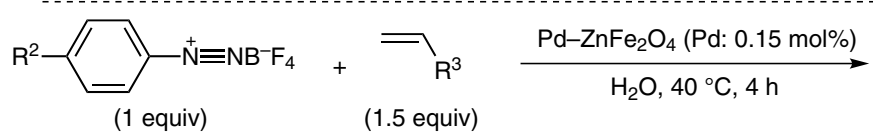<smiles>[R]C=Cc1ccc([R])cc1</smiles>
$80-87 \%$ yield, 10 examples

Selected results:

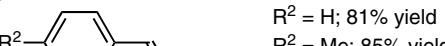
$\mathrm{R}^{2}=\mathrm{Me} ; 85 \%$ yield COOEt $R^{2}=\mathrm{OH} ; 85 \%$ yield

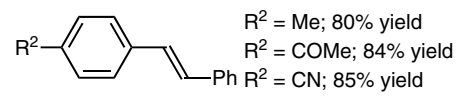
$\mathrm{R}^{2}=\mathrm{CN} ; 85 \%$ yield

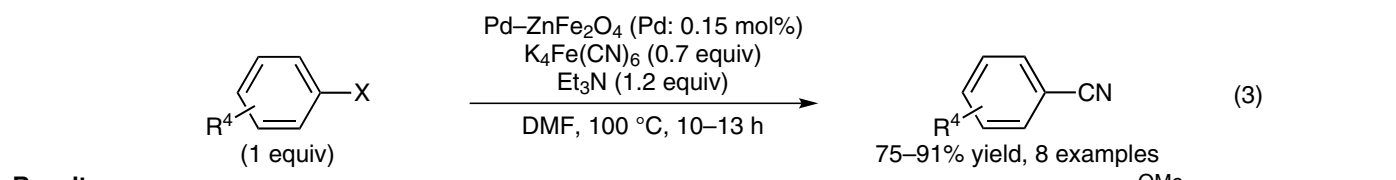

Results:
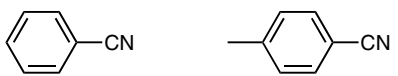

$\mathrm{O}_{2} \mathrm{~N}-\mathrm{CN}$<smiles>N#Cc1ccc(Cl)cc1</smiles>

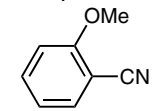

$90 \%$ yield $(X=I, 10 h) \quad 85 \%$ yield $(X=I, 11 \mathrm{~h}) \quad 91 \%$ yield $(X=I, 10 h) \quad 86 \%$ yield $(X=I, 10 h) \quad 75 \%$ yield $(X=I, 12 h)$ $81 \%$ yield $(X=B r, 12 h) \quad 83 \%$ yield $(X=B r, 13 h) \quad 85 \%$ yield $(X=B r, 12 h)$

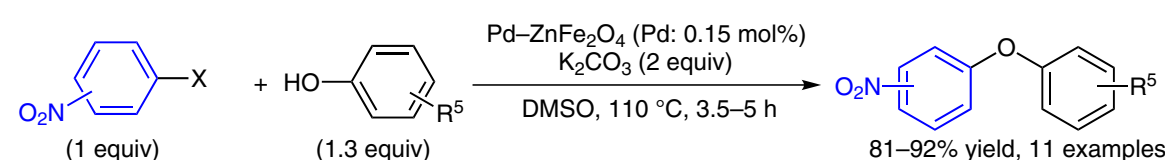

Selected results:
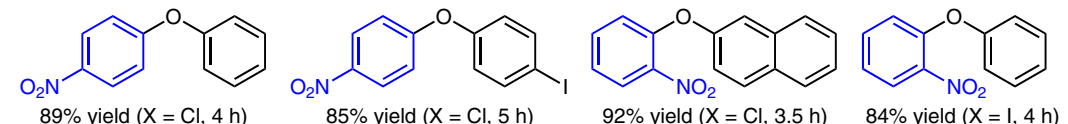

Significance: The superparamagnetic $\mathrm{Pd}-$ $\mathrm{ZnFe}_{2} \mathrm{O}_{4}$ catalyst was prepared by adding palladium nanoparticles into a suspension of $\mathrm{ZnFe}_{2} \mathrm{O}_{4}$ magnetic nanoparticles in water. $\mathrm{Pd}-\mathrm{ZnFe}_{2} \mathrm{O}_{4}$ catalyzed the Sonogashira coupling (8 examples, eq. 1), the Heck-Matsuda coupling (10 examples, eq. 2), the cyanation of aryl halides (8 examples, eq. 3) and the Ullman coupling (11 examples, eq. 4).

SYNFACTS Contributors: Yasuhiro Uozumi, Aya Tazawa Synfacts 2014, 10(1), 0104 Published online: 13.12.2013 Dol: 10.1055/s-0033-1340396; Reg-No.: Y13713SF
Comment: In the Sonogashira coupling of iodobenzene with phenylacetylene and the Ullmann coupling of 4-nitrochlorobenzene with phenol, the catalyst was recovered and reused twice without significant loss of catalytic activity. 


\section{Cyclic Peptide Synthesis Using Peptidyl Salicylaldehyde Esters}

Polymer-Supported

Synthesis

\section{Key words}

cyclic peptides

solid-phase peptide synthesis

cyclization

salicylaldehyde esters<smiles>NCOc1ccccc1O</smiles>

MBHA resin

$\mathrm{HO}$,

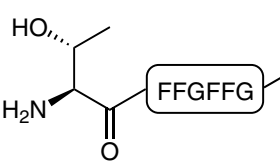

3<smiles>CC(=O)Oc1ccccc1/C=C/C(N)=O</smiles>

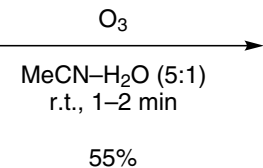

$55 \%$<smiles>CC(O)C(NC(=O)CNC(=O)C(Cc1ccccc1)NC(=O)C(Cc1ccccc1)NC(=O)CNC(=O)C(Cc1ccccc1)NC(=O)C(Cc1ccccc1)NC(=O)C(Cc1ccccc1)NC(=O)CNC(=O)Cc1ccccc1)C(C)O</smiles>

mahafacyclin B

$\mathrm{F}=$ phenylalanine, $\mathrm{G}=$ glycine

1. py, $\mathrm{AcOH}-\mathrm{F}_{3} \mathrm{CCH}_{2} \mathrm{OH}(1: 1: 2)$ 2. TFA $56 \%$ (2 steps)<smiles>CNC(=O)NC(=O)/C=C/c1ccccc1O</smiles>

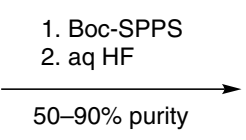<smiles>CCCC(=O)Oc1ccccc1C=O</smiles>

\section{$50-90 \%$ purity}

Significance: A protocol for the solid-phase synthesis of cyclopeptides was described. Starting from $\mathrm{MBHA}$ resin and $\mathbf{1}$, peptide $\mathbf{3}$ was prepared in $50-90 \%$ purity utilizing Boc-SPPS. Ozonolysis of $\mathbf{3}$ afforded a salicylaldehyde ester peptide $\mathbf{4}$ in $55 \%$ yield (other 15 examples: $42-89 \%$ yield). The reaction of $\mathbf{4}$ in the mixture of pyridine, acetic acid and 2,2,2-trifluoroethanol (1:1:2) followed by TFA treatment gave mahafacyclin $B$ in $56 \%$ yield over two steps (other 7 examples: 29-65\% yield).
Comment: The present cyclization of salicylaldehyde ester peptides bearing a Thr or Ser N-terminal residue (5) proceeds via the formation of salicylidene $\mathrm{N}, \mathrm{O}$-acetals $\mathbf{6}$. Li's group reported a similar approach on the cyclic peptide synthesis independently (C. T. T. Wong et al. Angew. Chem. Int. Ed. 2013, 52, 10212).

SYNFACTS Contributors: Yasuhiro Uozumi, Yoichi M. A. Yamada, Takuma Sato

Synfacts 2014, 10(1), 0105 Published online: 13.12.2013

Dol: 10.1055/s-0033-1340400; Reg-No.: Y14113SF 


\section{Category}

Polymer-Supported Synthesis

\section{Key words}

phenols

aryl halides

O-arylation

diaryl ethers
Y.-P. ZHANG, * Y.-C. JIAO, Y.-S. YANG, * C.-L. LI (LANZHOU UNIVERSITY OF TECHNOLOGY, P. R. OF CHINA)

Ligand-Free Catalytic System for the Synthesis of Diarylethers over $\mathrm{Cu}_{2} \mathrm{O} / \mathrm{Cu}-\mathrm{CNTs}$ as Heterogeneous Reusable Catalyst

Tetrahedron Lett. 2013, 54, 6494-6497.

\section{$\mathrm{Cu}_{2} \mathrm{O} / \mathrm{Cu}-\mathrm{CNTs}$ Catalyzed the O-Arylation of Phenols with Aryl Halides}

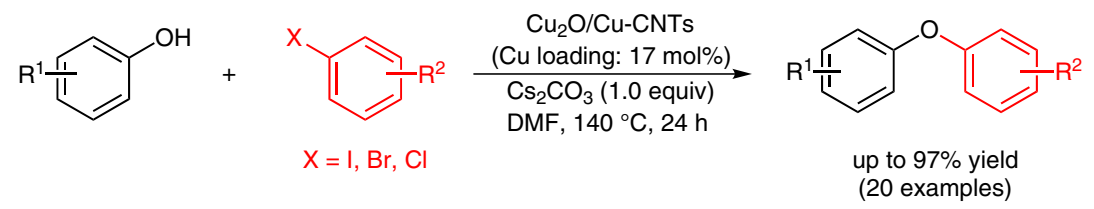

Selected examples:

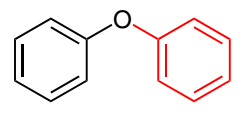

$94 \%$ yield $(X=I)$

$96 \%$ yield $(X=\mathrm{Br})$ $32 \%$ yield $(X=C l)$

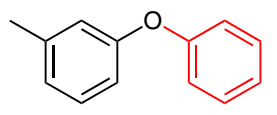

$77 \%$ yield $(X=1)$ $65 \%$ yield $(X=B r)$<smiles>O=Cc1ccc(Oc2ccccc2)cc1</smiles>

$83 \%$ yield $(\mathrm{X}=\mathrm{Br})$<smiles>Cc1ccc(Oc2ccccc2)cc1</smiles>

$45 \%$ yield $(\mathrm{X}=\mathrm{Cl})$<smiles>O=Cc1ccccc1Oc1ccccc1</smiles>

$50 \%$ yield $(\mathrm{X}=\mathrm{Cl})$<smiles>Cc1ccc(Oc2ccccc2)cc1</smiles>

$97 \%$ yield $(\mathrm{X}=\mathrm{Br})$<smiles>Brc1ccccc1Oc1ccccc1</smiles>

$42 \%$ yield $(X=I)$ $25 \%$ yield $(X=B r)$<smiles>Cc1ccc(Oc2ccccc2C=O)cc1</smiles>

$55 \%$ yield $(\mathrm{X}=\mathrm{Cl})$
Significance: $\mathrm{Cu}_{2} \mathrm{O} / \mathrm{Cu}$-Coated carbon nanotubes $\left(\mathrm{Cu}_{2} \mathrm{O} / \mathrm{Cu}\right.$-CNTs) catalyzed the O-arylation of phenols with aryl halides under ligand-free conditions to give the corresponding diaryl ethers in up to $97 \%$ yield (20 examples).
Comment: $\mathrm{Cu}_{2} \mathrm{O} / \mathrm{Cu}-\mathrm{CNTS}$ were recovered by filtration and reused three times without significant loss of catalytic activity. Lee and co-workers have previously reported the preparation and characterization of $\mathrm{Cu}_{2} \mathrm{O} / \mathrm{Cu}-\mathrm{CNTS}$ (Scr. Mater. 2008, 58, 1010).

SYNFACTS Contributors: Yasuhiro Uozumi, Shiguang Pan 


\section{Preparation of Nitrones Using $\gamma-\mathrm{Fe}_{2} \mathrm{O}_{3} @ \mathrm{SiO}_{2}-$ $\mathrm{H}_{3} \mathrm{PW}_{12} \mathrm{O}_{40}$}

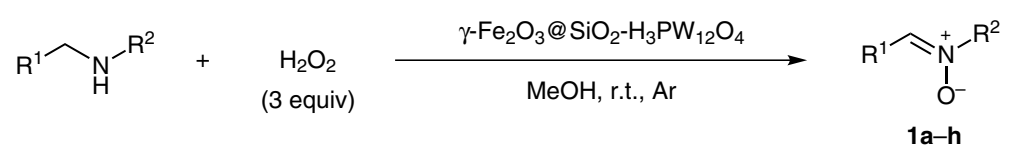

Results:<smiles>[O-]/[N+](=C/c1ccccc1)Cc1ccccc1</smiles>

$1 \mathrm{a}$

$2 \mathrm{~h}, 85 \%$ yield<smiles>CCCC=[N+]([O-])CCCC</smiles>

$12 \mathrm{~h}, 70 \%$ yield<smiles></smiles>

$1 \mathrm{~b}$ $2 \mathrm{~h}, 90 \%$ yield<smiles>COC(=O)C1=[N+]([O-])CCC1</smiles>

$1 \mathbf{f}$<smiles>COc1ccccc1C=[N+]([O-])Cc1ccccc1OC</smiles>

1c

$1 \mathrm{~h}, 87 \%$ yield<smiles>C[N+]([O-])=Cc1ccccc1</smiles>

$\mathbf{1 g}$
$3 \mathrm{~h}, 53 \%$ yield<smiles>CC(C)(C)[N+]([O-])=Cc1ccccc1</smiles>

$1 d$ $4 \mathrm{~h}, 85 \%$ yield<smiles>CCCC[N+]([O-])=Cc1ccccc1</smiles>

$1 \mathrm{~h}$
Significance: The oxidation of secondary amines by superparamagnetic tungstophosphoric acid supported on silica-encapsulated $\gamma-\mathrm{Fe}_{2} \mathrm{O}_{3}(\gamma$ $\mathrm{Fe}_{2} \mathrm{O}_{3} @ \mathrm{SiO}_{2}-\mathrm{H}_{3} \mathrm{PW}_{12} \mathrm{O}_{40}$ ) was carried out with an aqueous hydrogen peroxide as oxidant to give the corresponding nitrones $\mathbf{1 a}-\mathbf{h}$ in up to $90 \%$ yield.
Comment: The $\gamma-\mathrm{Fe}_{2} \mathrm{O}_{3} @ \mathrm{SiO}_{2}-\mathrm{H}_{3} \mathrm{PW}_{12} \mathrm{O}_{40}$ nanoparticles were readily recovered by an external magnet and reused three times without significant loss of catalytic activity ( $1^{\text {st }}$ reuse: $\mathbf{1 a} 85 \%$ yield, $3^{\text {rd }}$ reuse: 1 a $80 \%$ yield). The authors previously reported the preparation of $\gamma-\mathrm{Fe}_{2} \mathrm{O}_{3} @ \mathrm{SiO}_{2}-$ $\mathrm{H}_{3} \mathrm{PW}_{12} \mathrm{O}_{40}$ and its application to the synthesis of formamidines (J. Mol. Struct. 2012, 1027, 156).
Key words

nitrones

secondary amines

oxidation

heterogeneous catalysis 


\section{Category}

Polymer-Supported Synthesis

\section{Key words}

palladium on activated charcoal

bismuth

tellurium

aerobic oxidative esterification

primary alcohols
A. B. POWELL, S. S. STAHL* (UNIVERSITY OF WISCONSIN-MADISON, USA)

Aerobic Oxidation of Diverse Primary Alcohols to Methyl Esters with a Readily Accessible Heterogeneous Pd/Bi/Te

Catalyst

Org. Lett. 2013, 15, 5072-5075.

\section{Oxidative Esterification of Primary Alcohols with a $\mathrm{Pd} / \mathrm{Bi} / \mathrm{Te}$ Catalyst}

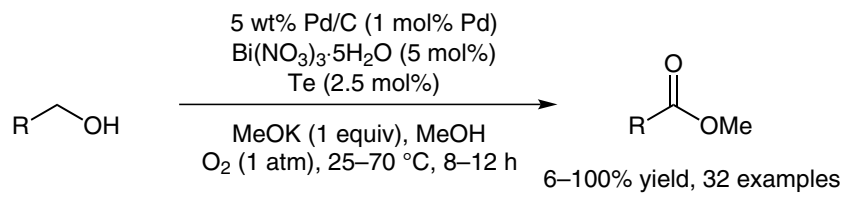

Typical results:

$92 \%$ yield<smiles>COC(=O)c1cccc(N(C)C)c1</smiles>

$87 \%$ yield<smiles>COC(=O)c1cccs1</smiles>

92\% yield<smiles>COC(=O)C12CC3CC(CC(C3)C1)C2</smiles>

95\% yield<smiles>COC(=O)c1ccc(OC)cc1</smiles>

$92 \%$ yield<smiles>COC(=O)c1cccc(F)c1</smiles>

$100 \%$ yield<smiles>COC(=O)c1ccccn1</smiles>

$43 \%$ yield<smiles>COC(=O)CCc1ccccc1</smiles>

$90 \%$ yield<smiles>COC(=O)c1ccc(C(F)(F)F)cc1</smiles>

$76 \%$ yield<smiles>COC(=O)c1ccc(Cl)cc1</smiles>

$70 \%$ yield<smiles>COC(=O)c1ccc(Br)cc1</smiles>

$6 \%$ yield<smiles>COC(=O)c1ccc2c(c1)OCO2</smiles>

$78 \%$ yield

$82 \%$ yield<smiles>COC(=O)/C=C/c1ccccc1</smiles><smiles>COC(=O)C(C)(C)C(C)(C)C</smiles><smiles>COC(=O)C1CCCCC1</smiles>

$62 \%$ yield

$90 \%$ yield<smiles>COC(=O)c1ccco1</smiles>

$87 \%$ yield<smiles>COC(=O)C1CCOC1</smiles>

$85 \%$ yield<smiles>COC(=O)CCCNC(=O)c1ccccc1</smiles>

$70 \%$ yield
Significance: Palladium on activated charcoal ( $\mathrm{Pd} / \mathrm{C}, 5 \mathrm{wt} \%$, purchased from Sigma-Aldrich) in combination with $\mathrm{Bi}\left(\mathrm{NO}_{3}\right)_{3} \cdot 5 \mathrm{H}_{2} \mathrm{O}$ and Te catalyzed the aerobic oxidative esterification of primary alcohols to give the corresponding methyl esters in 6$100 \%$ yield (32 examples, eq. 1).
Comment: In the absence of $\mathrm{Bi}\left(\mathrm{NO}_{3}\right)_{3} \cdot 5 \mathrm{H}_{2} \mathrm{O}$ and $\mathrm{Te}$, the oxidative esterification of 1 -octanol gave methyl octanoate in $16 \%$ yield. The catalytic activity of palladium on activated charcoal was superior to that of palladium on carbon and alumina (purchased from Sigma-Aldrich). 